\title{
Factors associated with vaccination against Influenza A (H1N1) in the elderly
}

\author{
FATORES ASSOCIADOS À VACINAÇÃO CONTRA INFLUENZA A (H1N1) EM IDOSOS \\ FACTORES ASOCIADOS A LA VACUNACIÓN CONTRA LA INFLUENZA A (H1N1) EN \\ ADULTOS MAYORES
}

\section{Janaína Fonseca Victor ${ }^{1}$, Gabriele Dias Gomes ${ }^{2}$, Luana Rodrigues Sarmento ${ }^{2}$, Arethusa Morais de Gouveia Soares ${ }^{3}$, Fernanda Rochelly do Nascimento Mota ${ }^{4}$, Bruna Michelle Belém Leite ${ }^{5}$ Edson Silva Soares ${ }^{6}$, Maria Josefina da Silva ${ }^{7}$}

\begin{abstract}
This study aimed to investigate the sociodemographic, clinical and behavioral factors and receiving information about the vaccine against pandemic influenza A (H1N1) associated with vaccination of elderly people. Study of quantitative and transversal nature, in which 286 elderly residents in Fortaleza, CE, Brazil participated. The association between variables was analyzed by the Pearson chi-square test, considering a $95 \%$ confidence interval and significance level $(p \leq 0.05)$. The results revealed that, unlike the sociodemographic characteristics, many clinical, behavioral and informational aspects correlated significantly with adherence to Influenza A (H1N1) vaccination. It is believed that the findings can be used in strategies to control and prevent infection by viral subtypes within the elderly population, extensible even to other vaccine-preventable diseases, especially in light of possible future pandemics.
\end{abstract}

\section{RESUMO}

Objetivou-se investigar os fatores sociodemográficos, clínicos, comportamentais e o recebimento de informações sobre a vacina contra a Influenza pandêmica A (H1N1) associados à vacinação de idosos. Estudo de natureza quantitativa e transversal, do qual participaram do 286 idosos residentes em Fortaleza, CE, Brasil. A associação entre as variáveis foi analisada por meio do teste Qui-quadrado de Pearson, considerando-se nível de significância de $95 \%(p \leq 0,05)$. Os resultados revelaram que, diferentemente das características sociodemográficas, muitos aspectos clínicos, comportamentais e informacionais apresentaram correlação estatisticamente significativa com a adesão à vacina Influenza A (H1N1). Acredita-se que os achados possam ser empregados em estratégias de controle e prevenção da infecção pelo subtipo viral junto à população idosa, extensíveis, inclusive, a outros agravos imunopreveníveis, especialmente diante de possíveis pandemias futuras.

DESCRITORES
Idoso
Imunização
Vacinas contra influenza
Vírus da Influenza A subtipo H1N1

\section{RESUMEN}

El objetivo fue investigar los factores sociodemográficos, clínicos, de comportamiento y el proceso de recepción de información, asociados a la vacunación contra la influenza pandémica $A(H 1 N 1)$ en adultos mayores. Corresponde a un estudio cuantitativo y transversal en el cual participaron 286 adultos mayores residentes en Fortaleza, CE, Brasil. La asociación entre variables se analizó mediante la prueba de chicuadrado de Pearson, considerándose un nivel de significación de $95 \%(p \leq 0,05)$. Los resultados señalaron que, a diferencia de las características sociodemográficas, muchos aspectos clínicos, de comportamiento y relacionados con la entrega de información presentaron una correlación estadísticamente significativa con la adhesión a la vacuna contra la influenza A (H1N1). Estos resultados podrán ser utilizados en estrategias de control y prevención de la infección por el subtipo viral en la población estudiada, incluso, en otras enfermedades inmunoprevenibles y sobre todo en posibles pandemias futuras.

\section{DESCRIPTORES}

Anciano

Inmunización

Vacunas contra la influenza

Subtipo H1N1 del Virus de la Influenza A

\footnotetext{
${ }^{1} \mathrm{PhD}$ in Nursing. Associate Professor II, Department of Nursing, Federal University of Ceara, Fortaleza, CE, Brazil. janainavictor@uol.com.br 22 Nurse graduated from the Federal University of Ceara. ${ }^{3}$ Master of Nursing. Nurse at Municipal Health Department of Fortaleza. ${ }^{4}$ Nurse. Master's Student, Nursing Graduate Program , Federal University of Ceara. ${ }^{5}$ Master of Nursing. Professor, Undergraduate Nursing, College of Education and Culture of Ceara. ${ }^{6}$ Masters in Public Health. I Assistant Professor, Department of Physical Education, Federal University of Ceara. ${ }^{7}$ PhD in Nursing. Associate Professor II, Coordinator of Undergraduate Nursing, Federal University of Ceara.
} 


\section{INTRODUCTION}

The Influenza type A viruses cause acute respiratory diseases with high transmissibility. This virus has been responsible for major pandemics such as the Spanish flu, Asian-Hong Kong flu and, more recently, the Swine Flu as it became a popularly known infection caused by a new virus subtype ${ }^{(1)}$. It is impossible to predict exactly when a new pandemic will occur and the monitoring of the virus and the epidemiological situation is an ongoing work of national and international health organizations ${ }^{(2)}$.

In early 2009, the first cases of Influenza A (H1N1) were registered in Mexico, which quickly spread for the world ${ }^{(1)}$. The declaration of the pandemic confirmed the movement of an emerging virus resulting from the genetic recombination of swine, avian and human virus $^{(3-4)}$. In the same year, 905 cases of Influenza A (H1N1) have been confirmed in 23 Brazilian states and in the Federal District ${ }^{(5)}$.

Because it was an emerging virus at that time, there had not been an immunobiological available, which required laboratories and research centers to do rapid investment in technology for the production, still in 2009, of the vaccine to prevent the pandemic virus.

In 2010, the World Health Organization (WHO) announced the post-pandemic phase, from which should be intensified and monitored preventive actions, especially in relation to vulnerable groups such as children, elderly, immune-compromised, cardiopathic and pneumopathic people, since the virus A (H1N1) has greater potential to cause morbidity and mortality in these groups $^{(1,6)}$. WHO indicates vaccination as a primary prevention strategy for reducing infections, hospitalizations and deaths ${ }^{(7)}$.

In Brazil, the National Strategy for Vaccination against the Pandemic Influenza virus A (H1N1) began in 2010, reaching more than $88 \%$ coverage ${ }^{(1)}$. Since 2011 , immunization against Influenza A (H1N1) became part of the national immunization schedule, in the form of trivalent immunobiological (associated with two other viruses subtypes), and people aged equal or greater than 60 years remained one of the target groups ${ }^{(7)}$.

In the post-pandemic period, with the existence of an effective immunobiological, the need for studies on aspects of adherence to vaccination emerged. With regard to specific groups, particularly the elderly, the investigation of personal and behavioral aspects proved to be especially relevant, as these individuals are at a stage in life of great vulnerability ${ }^{(8)}$. Moreover, in this group such factors are translated into actions, attitudes and beliefs that may interfere with adherence and maintenance of actions aimed at disease prevention and health promotion ${ }^{(9)}$.
Brazilian scientific production on Influenza A (H1N1) is still inexpressive, including those related to immunization against virus infection and associated factors with vaccine acceptance $^{(10)}$. Knowledge of these aspects may support specific and effective intervention strategies for different population groups.

This study aimed to investigate the association between sociodemographic, clinical, behavioral factors and receiving information about the Influenza A (H1N1) vaccine in elderly.

\section{METHOD}

Descriptive cross-sectional study conducted with elderly assisted by teams of the Family Health Strategy Program in Fortaleza - CE, Brazil. The sample was calculated using the formula for finite populations, using a 95\% confidence interval, sampling error of $4 \%$ and $11 \%$ of individuals in the age group of 60 years or older, living in Fortaleza, whose total population is $2,452,185$ inhabitants ${ }^{(11)}$. The calculation resulted in 235 elderly, however, the final sample size was 286 , since some elderly requested to participate as he/she saw another elderly taking part in the research.

Data were collected through individual interviews, conducted through the use of a form, from October 2010 to February 2011, in two of 12 Family Health Centers (FHC) that concentrate the largest number of elderly in Fortaleza. These were selected by simple draw.

A consecutive non-probabilistic sample was used. The interviews took place in the physical dependencies of FHC before or after they were attended. The sample included people aged equal or greater than 60 years who had no medical diagnosis of dementia with preserved verbal communication skills. Exclusion criteria were: people who do not recall taking vaccination against influenza $A$ (H1N1) and people who were present in FHC for clinical emergency care.

The collected data were entered into an electronic spreadsheet, using the Statistical Package for Social Sciences (SPSS) version 18.0, they were organized into tables, with absolute and relative frequencies, and analyzed descriptively and inferentially.

We analyzed the associations between the dependent variable (vaccination against influenza $A(H 1 N 1)$ ) and independent variables, ie, sociodemographic, behavioral and clinical characteristics and information about the vaccine. We used the chi-square test in the general inferential analysis and Fisher's exact test when compared to some $20 \%$ or more of the cells had expected value less than five, considering a 95\% confidence interval and a significance level of $\mathrm{p} \leq 0.05$.

Ethical principles for research involving human beings were respected, according to Resolution 196/96
Factors associated with vaccination against Influenza A (H1N1) in the elderly $B M B$, Soares ES, Silva MJ 
of the Ministry of Health/National Board of Health. The study was submitted to the Federal University of Ceara Research Ethics Committee and approved under protocol number 295/09.

\section{RESULTS}

The profile of the participants revealed: vaccination against Pandemic Influenza A (H1N1) (62.94\%), female (72.4\%), age group $60-65$ years $(39.5 \%)$, less than five years of study (40.5\%), married or in stable union (47.5\%), retired $(69.9 \%)$, residing in a trigenerational arrangement (25.9\%) and monthly personal income of one to two minimum wages $(73,4 \%)$.
Table 1 shows the sociodemographic characteristics of the elderly according to vaccination status. It was found that the variable age was significantly associated with vaccination $(p=0.05)$.

Table 2 shows a set of behavioral and clinical characteristics of the aged sample components, depending on their vaccine condition against Influenza A (H1N1). The behavioral and health variables that were associated with vaccination were: to be with chronic disease $(p=0.01)$, use of medication(s) of continuous use $(p=0.01)$, do checkups $(p=0.01)$, frequency of visits to the FHC $(p=$ 0.01 ), join groups promoted by health professionals ( $p=$ $0.02)$, not alcoholics $(p=0.02)$ and practice physical exercises $(p=0.01)$ (Table 2$)$.

Table 1 - Distribution of sociodemographic characteristics of the elderly, according to vaccination status against Influenza A (H1N1) - Fortaleza, CE, Brazil 2011.

\begin{tabular}{|c|c|c|c|c|c|}
\hline \multirow{3}{*}{ Characteristics } & \multicolumn{4}{|c|}{ Vaccination against Influenza $\mathbf{A}$} & \multirow{3}{*}{ p-value } \\
\hline & \multicolumn{2}{|c|}{ Yes } & \multicolumn{2}{|c|}{ No } & \\
\hline & $\mathbf{N}$ & $\%$ & $\mathbf{N}$ & $\%$ & \\
\hline \multicolumn{6}{|l|}{ Gender } \\
\hline Female & 135 & 65.2 & 72 & 34.8 & \multirow{2}{*}{0.19} \\
\hline Male & 45 & 57.0 & 34 & 43.0 & \\
\hline \multicolumn{6}{|l|}{ Age } \\
\hline $60-65$ years & 64 & 56.6 & 49 & 43.4 & \multirow{4}{*}{0.05} \\
\hline $66-70$ years & 53 & 76.8 & 16 & 23.2 & \\
\hline $71-75$ years & 32 & 59.3 & 22 & 40.7 & \\
\hline 76 or more & 31 & 62.0 & 19 & 38.0 & \\
\hline \multicolumn{6}{|l|}{ Education } \\
\hline Illiterate & 46 & 66.7 & 23 & 33.3 & \multirow{3}{*}{0.93} \\
\hline One to five years of study & 72 & 62.1 & 44 & 37.9 & \\
\hline Five years of study or more & 62 & 61.4 & 39 & 38.6 & \\
\hline \multicolumn{6}{|l|}{ Marital status } \\
\hline Single & 21 & 65.6 & 11 & 34.4 & \multirow{4}{*}{0.83} \\
\hline Marriage/stable union & 84 & 61.8 & 52 & 38.2 & \\
\hline Divorced/Separated & 22 & 56.4 & 17 & 43.6 & \\
\hline Widow & 53 & 67.1 & 26 & 32.9 & \\
\hline \multicolumn{6}{|l|}{ Occupation } \\
\hline Retired & 132 & 66.0 & 68 & 34.0 & \multirow{3}{*}{0.16} \\
\hline Pensioner & 24 & 64.9 & 13 & 35.1 & \\
\hline Formal work or commerce & 24 & 49.0 & 25 & 51.0 & \\
\hline \multicolumn{6}{|l|}{ People they live with } \\
\hline Spouse & 14 & 50.0 & 14 & 50.0 & \multirow{6}{*}{0.42} \\
\hline Spouse and child(ren) & 37 & 59.6 & 25 & 40.4 & \\
\hline Only with child(ren) & 33 & 68.7 & 15 & 31.3 & \\
\hline Trigenerational arrangement & 48 & 62.3 & 29 & 37.7 & \\
\hline Alone & 18 & 69.2 & 8 & 30.8 & \\
\hline Other arrangement & 30 & 66.7 & 15 & 33.3 & \\
\hline \multicolumn{6}{|l|}{ Personal income } \\
\hline Less than a minimum wage $(\mathrm{MW})^{* *}$ & 41 & 69.5 & 18 & 30.5 & \multirow{4}{*}{0.47} \\
\hline One to two MW & 128 & 61.0 & 82 & 39.0 & \\
\hline Three to four MW & 5 & 62.5 & 3 & 37.5 & \\
\hline More than four MW & 6 & 66.7 & 3 & 33.3 & \\
\hline
\end{tabular}

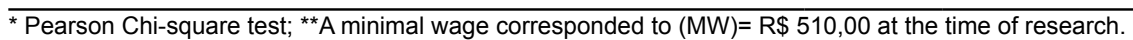


Table 2 - Distribution of clinical and behavioral characteristics of the elderly according to vaccination status against Influenza A (H1N1) - Fortaleza, CE, Brazil 2011.

\begin{tabular}{|c|c|c|c|c|c|}
\hline \multirow{3}{*}{ Characteristics } & \multicolumn{4}{|c|}{ Vaccination against Influenza $A$} & \multirow{3}{*}{ p-value* } \\
\hline & \multicolumn{2}{|c|}{ Yes } & \multicolumn{2}{|c|}{ No } & \\
\hline & $\mathbf{N}$ & $\%$ & $\mathbf{N}$ & $\%$ & \\
\hline \multicolumn{6}{|l|}{ Chronic disease } \\
\hline None & 23 & 40.4 & 34 & 59.6 & \multirow{3}{*}{0.01} \\
\hline One & 66 & 65.3 & 35 & 34.7 & \\
\hline Two or more & 91 & 71.1 & 37 & 28.9 & \\
\hline \multicolumn{6}{|l|}{ Use of medication(s) of continuous use } \\
\hline Yes & 157 & 68.5 & 72 & 31.5 & \multirow{2}{*}{0.01} \\
\hline No & 23 & 40.3 & 34 & 59.7 & \\
\hline \multicolumn{6}{|l|}{ Health monitoring } \\
\hline Yes & 157 & 68.5 & 72 & 31.5 & \multirow{2}{*}{0.01} \\
\hline No & 23 & 40.3 & 34 & 59.5 & \\
\hline \multicolumn{6}{|l|}{ Frequency of visits to the FHC } \\
\hline Weekly & 19 & 86.4 & 3 & 13.6 & \multirow{4}{*}{0.01} \\
\hline Fortnightly & 2 & 66.7 & 1 & 33.3 & \\
\hline Monthly & 87 & 68 & 41 & 32 & \\
\hline Occasionally & 72 & 54.1 & 61 & 45.9 & \\
\hline \multicolumn{6}{|l|}{ Participation in FHC groups } \\
\hline Yes & 51 & 75 & 17 & 25 & \multirow{2}{*}{0.02} \\
\hline No & 129 & 59.2 & 89 & 40.8 & \\
\hline \multicolumn{6}{|l|}{ Hospitalization during the last year } \\
\hline None & 169 & 64 & 95 & 36 & \multirow{3}{*}{0.13} \\
\hline One & 11 & 55 & 9 & 45 & \\
\hline More than one & 0 & 0 & 2 & 100 & \\
\hline \multicolumn{6}{|l|}{ Self-rated health } \\
\hline Excellent & 13 & 46.4 & 15 & 53.6 & \multirow{5}{*}{0.29} \\
\hline Good & 71 & 64 & 40 & 36 & \\
\hline Reasonable & 74 & 66.1 & 38 & 33.9 & \\
\hline $\mathrm{Bad}$ & 13 & 56.5 & 10 & 43.5 & \\
\hline Really bad & 9 & 75 & 3 & 25 & \\
\hline \multicolumn{6}{|c|}{ Independence in basic activities of daily living (BADL) $)^{* *}$} \\
\hline Yes & 166 & 62.9 & 98 & 37.1 & \multirow{2}{*}{0.94} \\
\hline No & 14 & 63.6 & 8 & 36.4 & \\
\hline \multicolumn{6}{|l|}{ Alcoholism } \\
\hline No & 173 & 89.6 & 95 & 35.4 & \multirow{2}{*}{0.02} \\
\hline Yes & 7 & 10.3 & 11 & 61.1 & \\
\hline \multicolumn{6}{|l|}{ Smoking } \\
\hline No & 171 & 64.3 & 95 & 35.7 & 008 \\
\hline Yes & 9 & 45 & 11 & 55 & 0.08 \\
\hline Practice of exercise & & & & & \\
\hline No practice & 88 & 56.1 & 69 & 43.9 & \\
\hline Less than 3 times per week & 40 & 74.1 & 14 & 25.9 & 0.01 \\
\hline 3 or more times per week & 52 & 69.3 & 23 & 30.7 & \\
\hline
\end{tabular}

* Pearson Chi-square test; **Basic activities of daily living (BADL): taking a shower, getting dressed, going to the restroom, transference, continence and feeding.

Table 3 presents the results regarding the association between the characteristics related to information about the vaccine against Influenza A (H1N1) and the elderly vaccination in our sample. Among these characteristics, having received prior information about the vaccine was significantly associated with adherence to influenza vaccination $(p=0.01)$. Other characteristics associated with immunization were: information about the vaccine through audiovisual media (TV) $(p=0.02)$, receiving information from health professionals $(p=0.01)$, hearing comments about the vaccine from other immunized persons $(p=0.01)$ and being influenced by these comments ( $p=0.05$ ) (Table 3 ). 
Table 3 - Distribution of variables related to information about the vaccine against Influenza A (H1N1), according to vaccination status of the elderly Fortaleza, CE, Brazil 2011

\begin{tabular}{|c|c|c|c|c|c|}
\hline \multirow{3}{*}{ Characteristics } & \multicolumn{4}{|c|}{ Vaccination against Influenza $A$} & \multirow{3}{*}{ p-value* } \\
\hline & \multicolumn{2}{|c|}{ Yes } & \multicolumn{2}{|c|}{ No } & \\
\hline & $\mathbf{N}$ & $\%$ & $\mathbf{N}$ & $\%$ & \\
\hline \multicolumn{6}{|l|}{ Receiving information about the vaccine } \\
\hline Yes & 178 & 67.2 & 87 & 32.8 & \multirow[t]{2}{*}{0.01} \\
\hline No & 2 & 9.5 & 19 & 90.5 & \\
\hline \multicolumn{6}{|l|}{ Information about the vaccine in the media ${ }^{* *}$} \\
\hline TV & 141 & 66.8 & 70 & 33.2 & \\
\hline Radio & 20 & 80 & 5 & 20 & 0.02 \\
\hline Posters & 25 & 71.4 & 10 & 28.6 & 0.06 \\
\hline \multirow[t]{2}{*}{ Other means } & 36 & 61 & 23 & 39 & 0.26 \\
\hline & & & & & 0.63 \\
\hline \multicolumn{6}{|c|}{ Information about the vaccine with the health professional** } \\
\hline Nurse & 41 & 80.4 & 10 & 19.6 & \multirow{3}{*}{0.01} \\
\hline Physician & 27 & 84.4 & 5 & 15.6 & \\
\hline Community Health Agent & 48 & 81.4 & 11 & 18.6 & \\
\hline \multicolumn{6}{|c|}{ Assigning importance to immunization with the vaccine } \\
\hline Yes & 171 & 69 & 77 & 31 & \multirow[t]{2}{*}{0.01} \\
\hline No & 9 & 23.7 & 29 & 76.3 & \\
\hline \multicolumn{6}{|c|}{ Access to the vaccine comments about others who were immunized } \\
\hline Yes & 37 & 100 & 4 & 0 & \multirow{2}{*}{0.01} \\
\hline No & 143 & 98.6 & 102 & 1.4 & \\
\hline \multicolumn{6}{|c|}{$\begin{array}{l}\text { Influence of comments from other immunized people on the deci- } \\
\text { sion to be vaccinated }\end{array}$} \\
\hline Yes & 17 & 53.1 & 15 & 46.9 & \multirow[t]{2}{*}{0.05} \\
\hline No & 163 & 71.4 & 91 & 28.6 & \\
\hline
\end{tabular}

${ }^{*}$ Pearson Chi-square test; ${ }^{* \star}$ Answer with more than one option.

\section{DISCUSSION}

The percentage of the elderly who received vaccination against Influenza A (H1N1) was higher to the elderly who have not adhered to vaccination, which denotes its acceptance. Similar percentages were found among the elderly population of municipalities in the Southeast and South of Brazil where they adhered to the Influenza vaccine against another viral subtype $(62.6 \% \text { and } 70.4 \% \text {, respectively })^{(12-13)}$. Study conducted in the international context, however, revealed predisposition about two times lower $(26.3 \%)$ of the general population to get vaccinated ${ }^{(14-15)}$.

Regarding sociodemographic characteristics, it was found that there was no statistical correlation between gender and vaccination of the elderly. However, females prevailed among the vaccinated, a distinct result was found for the Spanish population, in which males were $38 \%$ more likely to receive the vaccine against pandemic influenza ${ }^{(16)}$. Investigations carried out with elderly in two municipalities did not observe statistical association between gender and adherence to the seasonal influenza vaccine $^{(17-18)}$. Gender is a characteristic that also appears to be unrelated to the severity of infection and the risk of mortality by the pandemic $A(H 1 N 1)^{(19)}$.
In this study, age, sociodemographic characteristics among the investigated variable correlated statistically to vaccination. This correlation corroborates findings from studies conducted in $\mathrm{Spain}^{(20)}$ and Hong Kong ${ }^{(21)}$, in which age was shown to be a factor associated with intention to be vaccinated against the pandemic virus A (H1N1).

Study conducted among elderly people living in the municipality of southeastern Brazil observed greater acceptance of influenza vaccination among the oldest individuals ${ }^{(12)}$, differing from the present investigation, in which the younger elderly (60-65 years) had higher rates of vaccination. This result can be explained by the specificity of this age group, they are usually more active and has less limiting diseases ${ }^{(22)}$, which may interfere with spontaneous seeking for health services.

Regarding education, illiteracy prevailed among the vaccinated elderly, as other Brazilian research that had greater adherence to the seasonal influenza vaccine in elderly individuals who had up to four years of education ${ }^{(12)}$. Spanish investigation also indicated that the intention to be vaccinated against Influenza A (H1N1) has been declining in relation to educational level ${ }^{(20)}$. Regarding the infection through a viral subtype, education seems to have different relationships: higher cure rates were observed 
among people with secondary and university level of education, according to an epidemiological study conducted in Brazil with the general population ${ }^{(19)}$.

In this study, most people who adhered to the immunization showed this marital status, however, no statistical correlation with the dependent variable was observed. Previous research has shown that married people or in a stable union, in general, are more prone to vaccination against Influenza A (H1N1) ${ }^{(20)}$.

Regarding the clinical and behavioral aspects, the variables being a chronic disease carrier and, consequently, use of medications of continuous use were associated with vaccination. Similar findings were seen for seasonal influenza vaccine in a study performed with the elderly in Campinas (SP, Brazil), in which diabetes and hypertension were associated with vaccination ${ }^{(12)}$. Distinctively, a study conducted in Poland showed that chronic conditions have given cause for no adherence ${ }^{(23)}$. The correlation between presence of chronic disease(s) and acceptance of the vaccine in this study, is positive with respect to the prevention of morbidity and mortality associated with the pandemic virus, since certain chronic conditions commonly present in the elderly are risk factors for complications from infection with the $A$ (H1N1), such as hospitalization and death ${ }^{(24)}$.

Variables such as health monitoring, frequency of visits and participation in FHC groups were also statistically correlated with adherence to Influenza A (H1N1) vaccination, which corroborates the findings of another Brazilian study, in which association was found between immunization against influenza and the use of health services for the elderly ${ }^{(18)}$.

Regarding self-perceived health, most elderly who were vaccinated reported fair or good health and this characteristic showed no correlation with vaccination. However, a study in Poland showed the opposite: presenting good health was the most cited reason for the general population for no adherence to the vaccine ${ }^{(23)}$.

In this study, being independent to perform the BADL did not interfere with vaccination. Therefore, being a functional independent elderly was not a factor associated with adherence to the pandemic vaccine (H1N1). These results differ from those found in studies conducted in Taiwan, where they observed that elderly with difficulties in these activities were less likely to be regularly vaccinated against influenza(25).

In the present investigation, not being an alcoholic was correlated to vaccination among the elderly, differing from the results of study conducted in another Brazilian city, where the association between alcohol consumption and seasonal influenza vaccination was not observed ${ }^{(18)}$. A study in Chile found that alcoholism is an aggravating factor in infection with Influenza A (H1N1) ${ }^{(24)}$.

As to regular practice of exercises, we found that elderly who do not perform exercises were the ones who vaccinated the most against pandemic influenza $A$ (H1N1). Opposite result was revealed in a study of seasonal influenza, in which the practice of exercise in the elderly was associated with vaccination ${ }^{(18)}$. More specific studies are needed to clarify this association.

Regarding the information about the vaccine, most elderly, both vaccinated and non-vaccinated received some information about immunization against Influenza A (H1N1), a characteristic that was associated with adherence to vaccination. Study in southern Brazil also showed broad information on Influenza A (H1N1) among the population ${ }^{(26)}$.

Among the media that served as a source of information, television (TV) was the most mentioned media in this study. This was a variable that was correlated to the acceptance of the vaccine by the elderly. Research conducted in Spain showed the TV as the most cited media to access information about the vaccine, but without positive influence on the decision to be vaccinated ${ }^{(20)}$. Research conducted by the Polish population also revealed that audiovisual media had no significant role in promoting influenza vaccination ${ }^{(23)}$.

Disclosure of vaccination campaigns in the media is part of the strategies of the Brazilian Ministry of Health to encourage vaccination among the population ${ }^{(18)}$. A positive statistical correlation between receiving information about the vaccine (H1N1) and immunization through TV, observed in this study, allowed us to infer that media has a significant role for the elderly. However, it is suggested that further studies are conducted in order to more properly evaluate its effectiveness in promoting adherence to vaccination among specific populations to other immunobiologicals comprising the immunization schedule, considering not only moments of pandemics.

It is emphasized that the use of audiovisual media in general, have high financial costs and, although they can be efficient sources of access to information, especially during the occurrence of pandemics. Other means may prove to be more cost-effective for population adherence to vaccination, especially in non-pandemic periods.

On the role of health professionals as sources of information about immunization, there was a positive statistical correlation between vaccination and receiving information through these professionals, so that the elderly who were informed about the vaccine (H1N1) were more likely to be vaccinated. The finding reinforces and enhances the effectiveness of the performance of the health professional in the field of immunization ${ }^{(20,27)}$.

In this study, the most cited professional by vaccinated elderly was the Community Health Agent ( $\mathrm{CHA})$, followed by the nurse and physician, respectively, differing from international studies, in which the physician was the most cited $^{(15,23)}$. It is worth noting that the professionals mentioned in this study are active in the scenario of Primary
Factors associated with vaccination against Influenza A (H1N1) in the elderly $B M B$, Soares ES, Silva MJ 
Health Care (PHC). There is consensus that PHC is not just the main site where vaccination takes place but also the most frequent source of information about the need to be vaccinated $^{(23)}$. The $\mathrm{CHA}$ usually keeps close and continuous contact with the elderly in the community ${ }^{(28)}$ and this bond seems to influence adherence to immunization.

As for nurses, our findings corroborate the results of the Spanish investigation in which this professional was appointed by $28.2 \%$ of adults respondents as who provides more information about vaccines ${ }^{(20)}$. These data reinforce the role of the nurse as an essential element in elderly care, as they are often considered professional reference in the service to this audience, especially in the Family Health Strategy (FHS) ${ }^{(29)}$. Given their power to positively influence adherence to vaccination, it is imperative that health professionals incorporate into their work counseling strategies and recommendations for immunization, especially in the event of pandemics ${ }^{(30)}$.

There was a statistically significant correlation between having access to comments of people vaccinated and adherence to vaccination, but no studies were found addressing this aspect of vaccination against Influenza $A$ (H1N1) to be confronted with this finding. It is noteworthy, however, that there were no statistical correlation with respect to the variable influence of the comments on the decision to vaccinate, revealing that although the vaccinated elderly have received comments about the vaccine, this does not always influenced them.

A Spanish study showed that, for adults, the opinion of family and friends did not influence the decision to be vaccinated against influenza ${ }^{(20)}$. However, it would be interesting to conduct researches to assess the impact of comments from immunized people about vaccinating others, both among the elderly as in the general population. It is believed that knowing the type of comments and who make them, variables which were not investigated in this study, may better elucidate this issue.

\section{CONCLUSION}

The study provided important findings regarding factors associated with vaccination against Influenza $A$ (H1N1) among elderly Brazilians, such as clinical and behavioral factors as receiving information about the vaccine aspects, adding knowledge to an incipient area. It is believed that the information disclosed herein may be employed in the grounds of strategies to control and prevent infection by viral subtype with the elderly population, extensible even to other vaccine-preventable diseases, especially in light of possible future pandemics.

We encourage replication of the study in other research settings. We also suggest the development of new researches that may address the factors associated with adherence to the elderly trivalent influenza vaccine, which includes immune-protection to subtype A (H1N1) and two other subtypes, which currently composes the national vaccination schedule for people in this age group.

The limitations in the development of the study, one can cite the scarcity of research on vaccination against Influenza $A(H 1 N 1)$ among the elderly in the national literature, which restricts the discussion on the Brazilian reality. Due to the fact this is a new immunobiological against a new viral subtype, it is expected that scientific knowledge is expanded and consolidated in the coming years, as occurs with other emerging themes.

\section{REFERENCES}

1. Brasil. Ministério da Saúde; Secretaria de Vigilância em Saúde. Programa Nacional de Imunizações. Estratégia Nacional de Vacinação Contra o Vírus Influenza Pandêmico A (H1N1) 2009 [Internet]. Brasília; 2010 [citado 2013 abr. 22]. Disponível em: http://portal.saude.gov.br/portal/arquivos/pdf/ informe_tecnico_vacina_18_03_internet.pdf

2. Brasil. Ministério da Saúde; Secretaria de Vigilância em Saúde. Protocolo de Vigilância Epidemiológica da Influenza Pandêmica (H1N1) 2009: notificação, investigação e monitoramento [Internet]. Brasília; 2010 [citado 2013 abr. 22]. Disponível em: http://portal.saude.gov.br/portal/arquivos/pdf/protocolo_ve_influenza_2010.pdf

3. Vranjac A. Características dos casos notificados de Influenza A/H1N1. Rev Saúde Pública. 2009;43(5):900-4.

4. Machado AA. Infecção pelo vírus Influenza A (H1N1) de origem suína: como reconhecer, diagnosticar e prevenir. J Bras Pneumol. 2009;35(5):464-9.

5. Greco DB, Tupinambás U, Fonseca MO. Influenza A (H1N1): histórico, estado atual no Brasil e no mundo, perspectivas. Rev Med Minas Gerais. 2009;19(2):132-9.

6. Carmo EH, Oliveira WK. Risco de uma pandemia de influenza pelo vírus A (H1N1). Cad Saúde Pública. 2009;25(6):1192-3.

7. Brasil. Ministério da Saúde. Campanha Nacional de Vacinação contra a Influenza 2011[Internet]. Brasília; 2011 [citado 2013 abr. 22]. Disponível em: http://portal.saude.gov.br/portal/arquivos/pdf/informe_campanha_influenza_2011.pdf

8. Marin MJS, Santana FHS, Moracvick MYAD. The perception of hypertensive elderly patients regarding their health needs. Rev Esc Enferm USP [Internet]. 2012 [cited 2013 Apr 23];46(1):100-6. Available from: http://www. scielo.br/pdf/reeusp/v46n1/en_v46n1a14.pdf 
9. Victor JF, Ximenes LB, Almeida PC, Vasconcelos FF. Sociodemographic and clinical profile of elders who receive care in a Family Health Unit. Acta Paul Enferm. 2009; 22(1):49-54.

10. Luchs A. Profile of Brazilian scientific production on $A / H 1 N 1$ pandemic influenza. Ciênc Saúde Colet. 2012;17(6):1629-34.

11. Instituto Brasileiro de Geografia e Estatística. Indicadores Sociais Municipais: uma análise dos resultados do universo do censo demográfico 2010. Rio de Janeiro: IBGE; 2011.

12. Francisco PMSB, Barros MBA, Cordeiro MRD. Vacinação contra influenza em idosos: prevalência, fatores associados e motivos da não adesão em Campinas, São Paulo, Brasil. Cad Saúde Pública. 2011;27(3):417-26.

13. Prass L, Menezes HS, Abegg MP, Gomes MB, Souza WC, Cirino SLMB. Efetividade da vacina contra influenza em idosos em Porto Alegre. Rev AMRIGS. 2010;54(4):388-92.

14. Pérez-Rubio A, Eiros J, Castrodeza J. Evaluation of the influenza A H1N1 vaccination in Castilla and Leon regions, Spain. Med Clin. 2010;135(12):543-5.

15. Lu P, Gonzalez-Feliciano A, Ding H, Bryan LN, Yankey D, Monsell EA, et al. Influenza A (H1N1) 2009 monovalent and seasonal influenza vaccination among adults 25 to 64 years of age with high-risk conditions-United States, 2010. Am J Infect Control. 2013;41(8):702-9.

16. Rodríguez-Rieiro C, Esteban-Vasallo MD, Domínguez-Berjónb MF, Astray-Mochales J, Iniesta-Fornies D, BarrancoOrdoñez D, et al. Coverage and predictors of vaccination against 2009 pandemic H1N1 influenza in Madrid, Spain. Vaccine. 2011;29(6):1332-8.

17. Francisco PMSB, Donalisio MR, Barros MBA, César CLG, Carandina $L$, Golbaum $M$. Fatores associados à vacinação contra a influenza em idosos. Pan Am J Public Health. 2006;19(4):259-64.

18. Lima-Costa MF. Fatores associados à vacinação contra gripe em idosos na região metropolitana de Belo Horizonte. Rev Saúde Pública. 2008;42(1):100-7.

19. Lenzi L, Wiens A, Grochocki MHC, Pontarolo R. Study of the relationship between socio-demographic characteristics and new influenza A (H1N1). Braz J Infect Dis. 2011;15(5):457-61.

20. Tuells J, Caballero P, Nolasco A, Montagud E. Factores asociados a la predisposición a vacunarse contra la gripe pandémica A/H1N1 en población adulta del Departamento de Salud de Elche (España): influencia de las fuentes de información. An Sist Sanit Navar. 2012;35(2):251-60.
21. Lau JT, Yeung NC, Choi KC, Cheng MY, Tsui HY, Griffiths S. Acceptability of $A / H 1 N 1$ vaccination during pandemic phase of influenza A/H1N1 in Hong Kong: population based cross sectional survey. BMJ. 2009;339:b4164.

22. Vilarino MAM, Lopes MJM, Bueno ALM, Brito MRV. Idosos vacinados e não vacinados contra a influenza: morbidade relatada e aspectos sociodemográficos, Porto Alegre (RS, Brasil), 2004. Ciênc Saúde Colet. 2010;15(6):2879-86.

23. Kardas P, Zasowska A, Dec J, Stachurska M. Reasons for low influenza vaccination coverage: cross-sectional survey in Poland. Croat Med J. 2011;52(2):126-33.

24. Armstrong M, Fica A, Dabanch J, Olivares F, Fasce R, Triantafilo V. Morbilidad y mortalidad asociada a hospitalizaciones por influenza pandémica A (H1N1) 2009 en dos hospitales de la Región Metropolitana y evaluación de su impacto económico. Rev Chilena Infectol. 2012;29(6):664-71.

25. Chang YC, Huang N, Chen LS, Hsu SW, Chou YJ. Factors affecting repeated influenza vaccination among older people in Taiwan. Vaccine. 2013;31(2):410-6.

26. Milanesi R, Caregnato RCA, Wachholz NIR. Pandemia de Influenza A (H1N1): mudança nos hábitos de saúde da população, Cachoeira do Sul, Rio Grande do Sul, Brasil, 2010. Cad Saúde Pública. 2011;27(4):723-32.

27. Coe AB, Gatewood SBS, Moczygemba LR, Goode JVKR, Beckner JO. The use of the health belief model to assess predictors of intent to receive the novel (2009) H1N1 influenza vaccine. Inov Pharm. 2012;3(2):1-11.

28. Fernandes $\mathrm{HCL}$, Pavarini $\mathrm{SCl}$, Barham EJ, Mendiondo MSZ, Luchesi BM. Ageing and dementia: what do community health workers know? Rev Esc Enferm USP [Internet]. 2010 [cited $2013 \mathrm{Apr} 22$ ];44(3):782-8. Available from: http://www.scielo.br/pdf/reeusp/v44n3/en_33.pdf

29. Oliveira JCA, Tavares DMS. Elderly attention to health strategy in the family: action of nurses. Rev Esc Enferm USP [Internet]. 2010 [cited 2013 Apr 22];44(3):774-81. Available from: http://www.scielo.br/pdf/reeusp/v44n3/ en_32.pdf

30. Maurer J, Ushcer-Pines L, Harris KM. Perceived seriousness of seasonal and A (H1N1) influenzas, attitudes toward vaccination, and vaccine uptake among U.S. adults: does the source of information matter? Prev Med. 2010;51(2):185-7.
Correspondence addressed to: Janaína Fonseca Victor Rua Alexandre Baraúna, 449 - Bairro Rodolfo Teófilo CEP 60430-160 - Fortaleza, CE, Brazil 